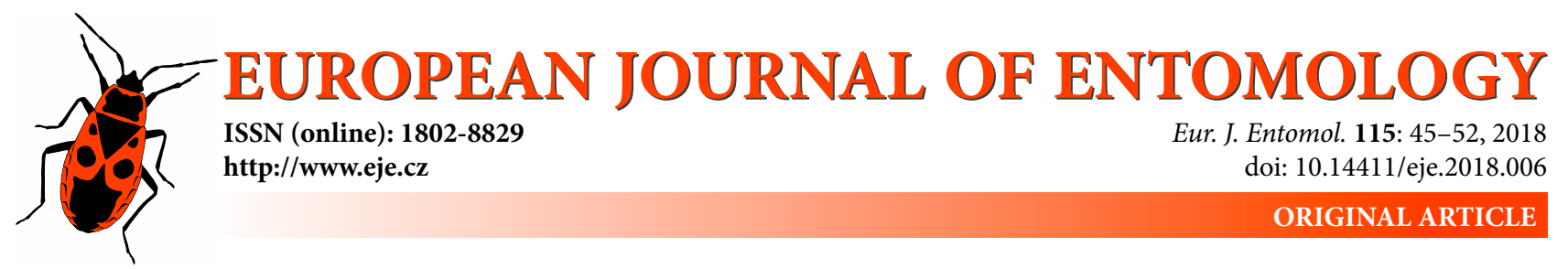

\title{
Loss of $Y$ chromosome may be a synapomorphy of the tribe Lepturini (Coleoptera: Cerambycidae: Lepturinae)
}

\author{
AnNe-Marie DUTRILLAUX and Bernard DUTRILLAUX*
}

Institut de Systématique, Evolution, Biodiversité, ISYEB-UMR7205-CNRS, UMPC, EPHE, Muséum National d'Histoire Naturelle, Sorbonne Universités, 57, rue Cuvier, CP 32 FR-75005 Paris, France; e-mails: amdutril@mnhn.fr, bdutrill@mnhn.fr

Key words. Cerambycidae, Lepturinae, Lepturini, systematics, karyotype, Y chromosome loss

\begin{abstract}
Phylogeny and higher classification of the cerambycid subfamily Lepturinae remain controversial. Here we report the results of a cytogenetic study of 18 species currently classified in Lepturini and 12 species in other tribes of Lepturinae (1 in Oxymirini, 1 in Rhamnusiini and 10 in Rhagiini) from Western Europe. The male sex chromosome formula is XY in all Rhagiini, Oxymirini and in Grammoptera ruficornis in the Lepturini (whose tribal placement may be doubtful), and XO in all the remaining Lepturini. The rarity of the $\mathrm{X} 0$ formula in other Cerambycidae indicates that the $\mathrm{Y}$ chromosome was lost in a common ancestor of the Lepturini or a subgroup thereof, indicating its monophyletic origin. The number of chromosomes is stable in the Lepturini that lack a Y chromosome (19,X/20,XX in males and females, respectively), but varies from 20 to 24 in the remaining genera, probably the consequence of evolution by chromosome fission. Whereas all the males with 19 or 20 chromosomes have an early gametogenesis, which is achieved before the imago stage, the species with more than 20 chromosomes seem to have a delayed male gametogenesis, which is still active in the young imagoes. The species of Rhagiini with 22 chromosomes may constitute a monophyletic group.
\end{abstract}

\section{INTRODUCTION}

Lepturinae constitute one of the large subfamilies of Cerambycidae, with more than 1000 species distributed mainly in the Northern hemisphere. Their systematic classification remains controversial; Bousquet et al. (2009) list 8 tribes: Desmocerini Blanchard, 1845, Encyclopini LeConte, 1873, Lepturini Latreille, 1802, Oxymirini Danilevsky, 1997, Rhagiini Kirby, 1837, Rhamnusiini Sama, 2009, Teledapini Pascoe, 1871 and Xylosteini Reitter, 1913, and the Necydalinae Lacordaire, 1825 is considered a separate subfamily. According to Svacha \& Lawrence (2014), lepturine classification is unsatisfactory, unstable and obviously non-phylogenetic. In Western Europe, only 5 of the above lepturine tribes are present, among which, Rhagiini and Lepturini are by far the most numerous, with at least 13 and 23 genera, respectively (Löbl \& Smetana, 2010). Surprisingly, chromosome studies of Lepturinae are very scarce and almost restricted to the pioneer studies of Teppner $(1966,1968)$. These old reports show that the karyotypes of the few species studied are composed of 20 or 22 chromosomes, numbers shared by most other Cerambycidae and other Polyphaga (Smith \& Virkki, 1978). Most of the specimens of Lepturini they studied are females, with an XX sex-chromosome formula and the very few males are XY. The scarcity of published data is probably explained by the difficulty of obtaining dividing cells of Lepturinae. Classically, chromosome studies are based on male germinal cells, but in this subfamily, male gametogenesis usually occurs very early, during the last larval and early pupal stages (Ehara, 1951; Dutrillaux, 2008). Thus, no dividing germinal cells can be obtained from adult males. This makes it necessary to use either adult somatic cells, which have a very low rate of proliferation in these taxa, or pre-imaginal stages difficult to identify. In contrast with literature data, our preliminary studies indicated that some species of Lepturinae have a 19, X and not a 20, XY male karyotype, thus suggesting a loss of a $\mathrm{Y}$ chromosome. The lack of a $\mathrm{Y}$ chromosome, frequent in some beetle families, such as Elateridae and Lampyridae, is rare in Cerambycidae. It is recorded in a single species, Stromatium barbatum Fabricius, 1775 (Cerambycinae), among the 140 chromosome formulae collected by Smith \& Virkki (1978), and in another species, Oncideres amputator (Fabricius, 1792), which belongs to the Lamiinae (Dutrillaux \& Dutrillaux, 2008). In this work, we investigate the sex chromosomes of males of Lepturinae with the aim of finding a relationship between $\mathrm{Y}$ chromosome loss and systematics. At least for the European species studied,

\footnotetext{
* Corresponding author; e-mail: bdutrill@mnhn.fr
} 
Table 1. Species of Lepturinae included in the cytogenetic study, with collection data (material from France if not stated otherwise), the stage of development and the organ or tissue successfully analysed.

\begin{tabular}{|c|c|c|}
\hline Tribe / Species & Origin & Stage (Tissue) \\
\hline $\begin{array}{l}\text { Rhagiini Kirby, } 1837 \\
\text { Acmaeops pratensis (Laicharting, 1784) } \\
\text { Brachyta interrogationis (Linnaeus, 1758) } \\
\text { Dinoptera collaris (Linnaeus, 1758) } \\
\text { Gaurotes virginea (Linnaeus, 1758) } \\
\text { Pachyta quadrimaculata (Linnaeus, 1758) } \\
\text { Pidonia lurida (Fabricius, 1792) } \\
\text { Rhagium bifasciatum Fabricius, 1775 } \\
\text { Rhagium mordax (DeGeer, 1775) } \\
\text { Rhagium sycophanta (Schrank, 1781) } \\
\text { Rhagium inquisitor (Linnaeus, 1758) }\end{array}$ & $\begin{array}{l}\text { Alpes (Queyras) } \\
\text { Alpes (Queyras) } \\
\text { Jura } \\
\text { Jura } \\
\text { Alpes (Savoie) } \\
\text { Jura } \\
\text { Compiègne forest } \\
\text { Compiègne forest } \\
\text { Fontainebleau forest } \\
\text { Fontainebleau forest, Alpes }\end{array}$ & $\begin{array}{l}\text { Eggs } \\
\text { Imago (mid-gut) } \\
\text { Imago (mid-gut) } \\
\text { Imago (mid-gut, gonads) } \\
\text { Imago (mid-gut), eggs } \\
\text { Imago (mid-gut) } \\
\text { Larva (gonads) } \\
\text { Larva (gonads) } \\
\text { Larva (gonads) } \\
\text { Larva (gonads) }\end{array}$ \\
\hline $\begin{array}{l}\text { Lepturini Latreille, } 1802 \\
\text { Alosterna tabacicolor (DeGeer, 1775) } \\
\text { Anastrangalia dubia (Scopoli, 1763) } \\
\text { Anastrangalia sanguinolenta (Linnaeus, 1760) } \\
\text { Anoplodera sexguttata (Fabricius, 1775) } \\
\text { Etorofus pubescens (Fabricius, 1787) } \\
\text { Grammoptera ruficornis (Fabricius, 1781) } \\
\text { Leptura aurulenta Fabricius, 1792 } \\
\text { Leptura quadrifasciata Linnaeus, 1758 } \\
\text { Lepturobosca virens (Linnaeus, 1758) } \\
\text { Pachytodes cerambyciformis (Schrank, 1781) } \\
\text { Pseudovadonia livida (Fabricius, 1776) } \\
\text { Rutpela maculata (Poda, 1761) } \\
\text { Stenurella melanura (Linnaeus, 1758) } \\
\text { Stenurella nigra (Linnaeus, 1758) } \\
\text { Stictoleptura scutellata (Fabricius, 1781) } \\
\text { Stictoleptura maculicornis (DeGeer, 1775) } \\
\text { Stictoleptura stragulata (Germar, 1824) } \\
\text { Stictoleptura rubra (Linnaeus, 1758) } \\
\end{array}$ & $\begin{array}{l}\text { Jura } \\
\text { Alpes (Savoie) } \\
\text { Pyrenees } \\
\text { Jura } \\
\text { Pyrenees } \\
\text { Jura } \\
\text { Fontainebleau forest } \\
\text { Alpes (Savoie) } \\
\text { Alpes (Savoie) } \\
\text { Alpes (Savoie) } \\
\text { Jura } \\
\text { Jura, Alpes (Savoie) } \\
\text { Alpes (Savoie) } \\
\text { Jura } \\
\text { Fontainebleau forest } \\
\text { Alpes (Savoie) } \\
\text { Spain, various localities } \\
\text { Alpes, Fontainebleau forest }\end{array}$ & $\begin{array}{l}\text { Imago (mid-gut), eggs } \\
\text { Imago (mid-gut) } \\
\text { Imago (mid-gut), eggs } \\
\text { Imago (mid-gut) } \\
\text { Imago (mid-gut), eggs } \\
\text { Imago (mid-gut, gonads) } \\
\text { Pupa (mid-gut, gonads) } \\
\text { Imago (mid-gut) } \\
\text { Imago (mid-gut) } \\
\text { Imago (mid-gut) } \\
\text { Imago (mid-gut) } \\
\text { Imago (mid-gut), eggs } \\
\text { Imago (mid-gut) } \\
\text { Imago (mid-gut) } \\
\text { Imago (mid-gut, ovaries) } \\
\text { Imago (mid-gut) } \\
\text { Imago (mid-gut) } \\
\text { Imago (mid-gut) }\end{array}$ \\
\hline $\begin{array}{l}\text { Oxymirini Danilevsky, } 1997 \\
\text { Oxymirus cursor (Linnaeus, 1758) }\end{array}$ & Czech Republic, Hluboká n/VIt. & Larva (mid-gut) \\
\hline $\begin{array}{l}\text { Rhamnusiini Sama, } 2009 \\
\text { Rhamnusium bicolor (Schrank, 1781) }\end{array}$ & Slovakia, environs of Štúrovo & Larva (mid-gut) \\
\hline
\end{tabular}

we show that all the males of species currently classified in Lepturini (Grammoptera ruficornis excepted) have an X0 sex formula, while all the males of Rhagiini and Oxymirini (plus G. ruficornis) have an XY sex formula.

\section{MATERIAL AND METHODS}

\section{Insects}

Most of the species studied were collected in France. They are listed in Table 1, with collecting place, stage of development and the tissues studied. Nomenclature used is that of Löbl \& Smetana (2010).

\section{Methods}

Mid-gut cells

After anaesthesia using ethyl acetate, the abdomen was removed and placed in a drop of an aqueous solution of $0.88 \mathrm{M}$ $\mathrm{KCl}$. The mid-gut was extracted, placed in $1 \mathrm{ml}$ of the same solution with the addition of colcemid and dissected to obtain a cell suspension. After $1 \mathrm{~h}$, this suspension was transferred to a microcentrifuge tube (VWR International SAS, Strasbourg, France) and centrifuged (5 min at about $800 \mathrm{~g}$ ). After elimination of the supernatant, the pellet was suspended in $0.5 \mathrm{ml}$ of a hypotonic solution (either a $0.55 \mathrm{M} \mathrm{KCl}$ solution or foetal calf serum diluted $1: 3$ in distilled water), where they were squashed in the tube and suspended using a piston (VWR) adjusted to the internal diameter of the tube. The volume was increased to $1.5 \mathrm{ml}$. After $10 \mathrm{~min}$, the cell suspension was centrifuged. The supernatant was replaced by
Carnoy I fixative (ethanol : acetic acid, $3: 1$ ), in which the cells were suspended and left for at least $30 \mathrm{~min}$. After one change of fixative, the cells were spread on wet and cold slides or conserved in the tube for a few days at $6^{\circ} \mathrm{C}$ before use. Slides were stained with Giemsa, photographed and C-banded according to Angus (1982). This technique was used for both adults and larvae.

\section{Testicular cells}

The same method was applied, except for the treatment with $0.88 \mathrm{KCl}$, which was reduced from $1 \mathrm{~h}$ to $10 \mathrm{~min}$. In most species, cell divisions were obtained only in larvae and pupae.

\section{Eggs}

They were gently cleaned and transferred into a micro-centrifuge tube containing 0.5 to $1 \mathrm{ml}$ of a $0.88 \mathrm{M} \mathrm{KCl}$ solution with added colcemid and squashed using a piston, as above. The rest of the technique is as for the mid-gut, but only diluted calf serum was used for the hypotonic shock. These techniques are derived from those of Dutrillaux \& Chevin (1968) and Angus (1982).

\section{RESULTS}

The chromosome numbers, sex chromosome formulae and morphology of the X chromosome of the 29 species studied are summarized in Tables 2 and 3, and karyotypes are shown in Figs 1-4. The scarce data in the literature are also included in the tables. 
Table 2. Sex and main chromosomal data of the specimens of Rhagiini, Oxymirini and Rhamnusiini studied. Sex chrom. - sex chromosome formula; X morph. - morphology of chromosome X; A - acrocentric; M - metacentric; SM - sub-metacentric; h+ - heterochromatin amplification; $2 \mathrm{n}$ - diploid chromosome number. Data from literature included. ${ }^{1}-$ only the chromosome number is given for the female.

\begin{tabular}{|c|c|c|c|c|c|c|}
\hline $\begin{array}{l}\text { Species of Rhagiini, } \\
\text { Oxymirini, Rhamnusiini }\end{array}$ & Sex & Sex chrom. & X morph. & $2 n$ & Figures & Source \\
\hline Acmaeops pratensis & Male, female & $X Y / X X$ & $\mathrm{M}$ & 22 & $1 d, e$ & This study \\
\hline Acmaeops proteus & Male & $\mathrm{Xy}_{\mathrm{p}}$ & $?$ & 22 & - & Smith, 1953 \\
\hline Brachyta interrogationis & Male & $X Y$ & SM & 20 & $1 \mathrm{a}$ & This study \\
\hline Dinoptera collaris & Male & $X Y$ & SM & 22 & 1c & This study \\
\hline Gaurotes virginea & Male & $X Y, X y_{p}$ & SM & 22 & $1 b$ & This study \\
\hline Gaurotes doris & Male & $?$ & $?$ & 22 & - & Ehara, 1956 \\
\hline Gaurotes suvorovi & Male & $X Y$ & $?$ & 22 & - & Ehara, 1956 \\
\hline Pachyta quadrimaculata & Male, female & $X Y / X X$ & SM & 20 & $1 \mathrm{~h}, \mathrm{i}$ & This study \\
\hline Pidonia lurida & Male, female & $X Y / X X$ & $A$ & 20 & $1 \mathrm{j}$ & This study \\
\hline Rhagium bifasciatum & Male & $\mathrm{Xy}_{\mathrm{p}}$ & $?$ & 20 & - & Teppner, 1968 \\
\hline Rhagium bifasciatum & Male & $X Y$ & $A$ & 20 & - & This study \\
\hline Rhagium inquisitor & Male & $X Y$ & SM & 20 & $1 \mathrm{k}, \mathrm{l}$ & This study \\
\hline Rhagium inquisitor & Male, female & $\mathrm{Xy}_{\mathrm{p}}{ }^{1}$ & $?$ & 20 & - & Teppner, 1968 \\
\hline Rhagium mordax & Male & $?$ & $?$ & 20 & - & Teppner, 1968 \\
\hline Rhagium mordax & Male & $X Y$ & SM & 20 & - & This study \\
\hline Rhagium sycophanta & Male & $X Y$ & SM & 20 & - & This study \\
\hline Oxymirus cursor & Male, female & $\mathrm{XY} / \mathrm{XX}$ & $\mathrm{SM}, \mathrm{h}+$ & 20 & 4 & This study \\
\hline Rhamnusium bicolor & Female & $X X$ & $A$ & 20 & - & This study \\
\hline
\end{tabular}

\section{Rhagiini}

(Table 2, Figs 1a-e and h-1)

\section{Chromosomes}

All the males have an XY and the 3 females studied have an XX sex formula. The X chromosome may be either acrocentric $(P$. lurida), or sub-metacentric (B. interrogation$i s)$, or metacentric (D. collaris). Its size is in the range of the smallest autosomes and the $\mathrm{Y}$ is punctiform. Thus, the sex chromosomes of species belonging to this tribe look like those of most other cerambycid beetles and may be plesiomorphic. The chromosome number of 20, recorded for the genera Rhagium Fabricius, 1775, Brachyta Fairmaire, 1864, Pachyta Dejean, 1821 and Pidonia Mulsant, 1863 is also quite standard in Cerambycidae, as in Polyphaga in general.

The karyotypes of 6 species, 3 from the literature and 3 from this study, belonging to the genera Acmaeops LeConte, 1850, Gaurotes LeConte, 1850 and Dinoptera Mulsant, 1863 comprise 22 chromosomes. The sizes of the autosomes of the species with 22 chromosomes ( $G$. virginea, $D$. collaris and A. pratensis, Fig. 1b-e) progressively decrease without a size gap. In contrast, in $P$. quadrimaculata, . lurida and B. interrogationis, there is a size discontinuity, with chromosome 1 much larger than the others. In species of the genus Rhagium, the size discontinuity is between chromosomes 2 and 3 (Fig. 1k and 1).

It proved very difficult to obtain C-banding, as frequently it was almost absent, very faint, or limited to the centromere region of a few autosomes. The X was C-banded in only a few species and the $\mathrm{Y}$ was always very pale (Fig. $1 \mathrm{e}, \mathrm{g}, \mathrm{i}, \mathrm{j}$ and $\mathrm{l})$. In spite of these difficulties, the variations in heterochromatin and chromosome morphology were sufficient to reveal that all the karyotypes differed from each other.

\section{Gametogenesis}

Although probably mostly young adults were captured (in May at low altitudes and June or early July above 1600 $\mathrm{m}$.), all the males with 20 chromosomes had completed their gametogenesis and only bouquets of spermatozoa were occasionally found in the testes. In contrast, we found that gametogenesis was still active in an adult of $G$. virginea $(2 \mathrm{n}=22)$, which provided us with $10+\mathrm{Xy}_{\mathrm{p}}$ metaphases I.

\section{Lepturini}

(Table 3, Figs 1f, g, 2, 3)

\section{Chromosomes}

All the females studied by us have a 20, XX karyotype, in agreement with the data in the earlier literature (Tables 2 and 3). Almost all the males (15 of 16 species) have a 19, X karyotype, which differs from the data of Teppner (1968) who proposes 20 chromosomes for the males of $A$. dubia and "Leptura ochracea" (a synonym of Anastrangalia reyi). The karyotypes of the species of Lepturini look fairly similar after Giemsa staining, with 9 pairs of metacentric or sub-metacentric autosomes. The karyotype of $R$. maculata (Figs 2h, 3h), however, differs with one pair of acrocentric autosomes. The $\mathrm{X}$ is most frequently sub-metacentric. In all these species, pair $\mathrm{N}^{\circ} 1$ is much larger than pair $\mathrm{N}^{\circ} 2$, as in some species of Rhagiini. The karyotype of G. ruficornis clearly differs from that of other Lepturini: it is composed of 24 chromosomes of regularly decreasing size and its male sex formula is XY. This karyotype is shown in Fig. 1f, g, near those of species of Rhagiini with 22 chromosomes (Fig. 1b-e), which facilitates their comparison and displays their resemblance.

C-banding was also hard to obtain and generally faint and not systematized. It was present in the region of the centromere of either all chromosomes, as in S. melanura 


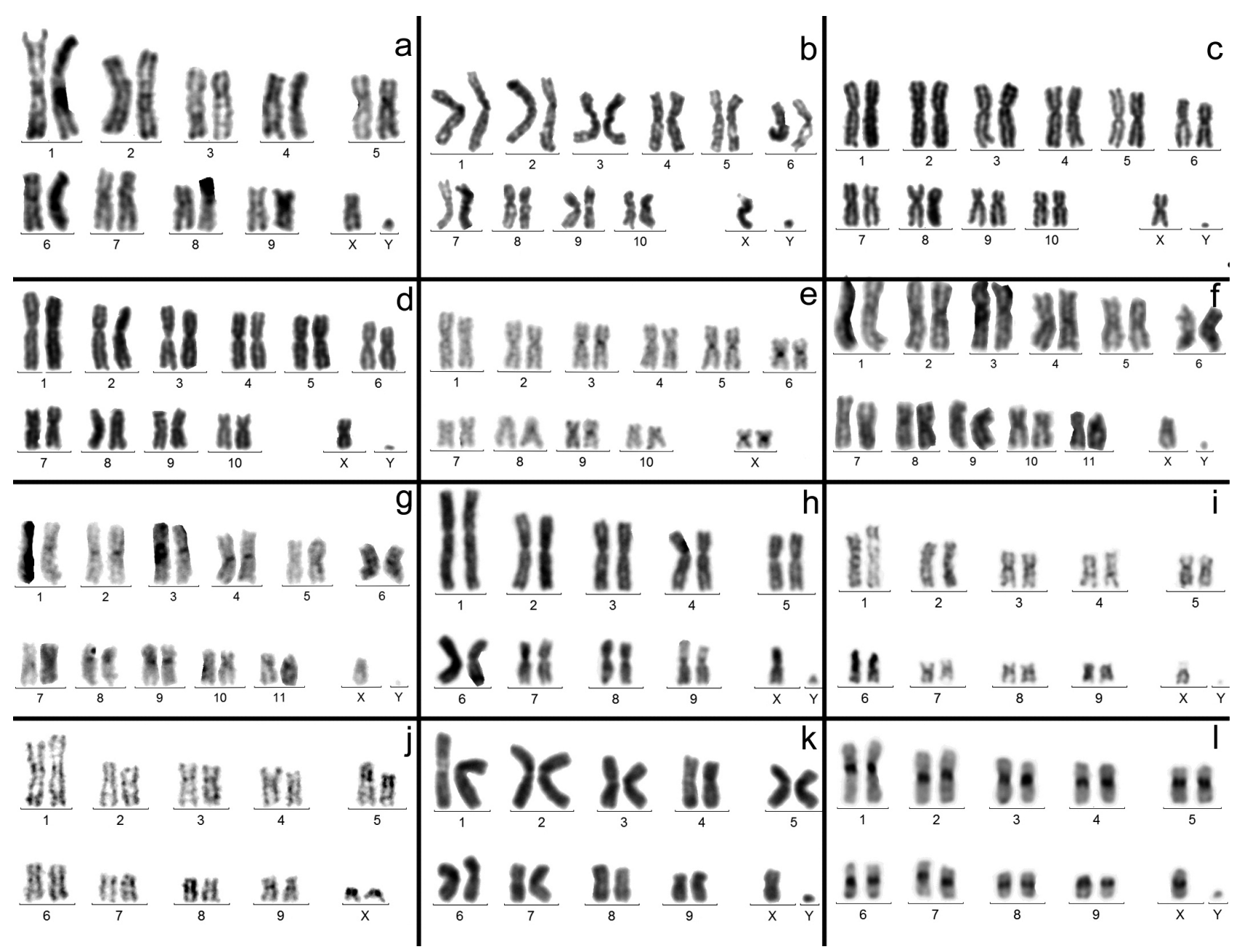

Fig. 1. Giemsa stained and C-banded male (or female, when indicated) karyotypes of Rhagiini and Lepturini (G. ruficornis): a - Brachyta interrogationis; $\mathrm{b}$ - Gaurotes virginea; c - Dinoptera collaris; $\mathrm{d}$ - Acmaeops pratensis; e - A. pratensis (female, C-banding); $\mathrm{f}, \mathrm{g}-\mathrm{Gram}$ moptera ruficornis (sequentially Giemsa stained and C-banded); h, i - Pachyta quadrimaculata (Giemsa staining and C-banding); j - Pidonia lurida (female, C-banding), k, I - Rhagium inquisitor (Giemsa staining and C-banding).

(Fig. 31), or only some chromosomes, and even lacking in many species (Fig. 3d-k). C-bands were occasionally present at telomeres (A. dubia and S. rubra, Fig. 3d and f) or in interstitial regions ( $S$. stragulata and $P$. cerambyciformis, Fig. $3 \mathrm{e}$ and $\mathrm{k}$ ). The centromere region of the $\mathrm{X}$ chromosome could be either C-banded as in A. dubia (Fig. 3d), or not, as in L. aurulenta (Fig. 3g).

\section{Gametogenesis}

In all but one species studied, male gametogenesis had ceased and only bouquets of spermatozoa were occasionally found in the testes. The exception was G. ruficornis, in which spermatocytes I at diakinesis were still present in the testicles of the adult. Their meioformula is $11+\mathrm{Xy}_{\mathrm{p}}$.

\section{Oxymirini}

(Table 2, Fig. 4)

The karyotype of $O$. cursor is composed of 18 autosomes with 2 pairs that are acrocentric. With a size gap between pairs 2 and 3, it generally looks like that of the genus Rhagium. The very large size of the sex chromosomes is however quite unusual. Their parallel and tightly associated chromatids indicate a heterochromatic composition, which is confirmed by their intense C-banding, especially on the Y chromosome.

\section{Rhamnusiini}

(Table 2)

Only one female larva of $R$. bicolor was studied; its karyotype was $2 \mathrm{n}=20$ and $\mathrm{XX}$ sex chromosomes.

\section{DISCUSSION}

\section{Chromosome $\mathrm{Y}$ loss may characterize Lepturini amongst Lepturinae}

The karyotypes of Rhagiini and Lepturini do not differ very much. Most of the females have 20 chromosomes and the males 19 or 20 chromosomes. The decrease from 20 to 19 is the consequence of the lack of chromosome Y, which occurs in the Lepturini, but not in the other tribes studied. In other Cerambycid beetles, the lack of chromosome Y is rare: $1 / 105$ species calculated from the Smith \& Virkki (1978) compilation and 1/104 non-Lepturini species in our own unpublished data. Thus, the males of Lepturinae, as those of Cerambycidae in general, originally had a Y chromosome, which was conserved in Rhagiini and Oxymirini, 
Table 3. Data on the sex of the specimens of Lepturini studied and their main chromosomal characters. Sex chrom. - sex chromosome formula; X morph. - morphology of chromosome X; A - acrocentric; $M$ - metacentric; SM - sub-metacentric; $2 n$ - chromosome number. Data from literature included. ${ }^{1}$ - given as Leptura ochracea in Teppner (1968).

\begin{tabular}{|c|c|c|c|c|c|c|}
\hline Species of Lepturini & Sex & Sex chrom. & X morph. & $2 n$ & Figures & Source \\
\hline Alosterna tabacicolor & Male, female & $\mathrm{X} / \mathrm{XX}$ & SM & $19 / 20$ & $2 a$ & This study \\
\hline Anastrangalia dubia & Male & $?$ & $?$ & 20 & - & Teppner, 1968 \\
\hline Anastrangalia dubia & Male & $\mathrm{x}$ & M & 19 & $2 b, 3 d$ & This study \\
\hline Anastrangalia reyi (Heyden, 1889) ${ }^{1}$ & Male, female & ? & $?$ & 20 & - & Teppner, 1968 \\
\hline Anastrangalia sanguinolenta & Female & $?$ & ? & 20 & - & Teppner, 1968 \\
\hline Anastrangalia sanguinolenta & Male & $\mathrm{X}$ & M & 19 & $2 c$ & This study \\
\hline Anoplodera sexguttata & Male & $\mathrm{x}$ & M & 19 & $2 d$ & This study \\
\hline Etorofus pubescens & Male & $x$ & A & 19 & $3 a$ & This study \\
\hline Grammoptera ruficornis & Male & $\mathrm{XY}, \mathrm{Xy}_{\mathrm{p}}$ & A & 24 & $1 \mathrm{f}, \mathrm{g}$ & This study \\
\hline Leptura aurulenta & Male, female & $X / X X^{p}$ & SM & $19 / 20$ & $2 g, 3 g$ & This study \\
\hline Leptura quadrifasciata & Female & ? & ? & 20 & - & Teppner, 1968 \\
\hline Leptura quadrifasciata & Male & $\mathrm{x}$ & SM & 19 & $2 \mathrm{i}, 3 \mathrm{j}$ & This study \\
\hline Lepturobosca virens & Male & $\mathrm{X}$ & SM & 19 & $2 \mathrm{j}$ & This study \\
\hline Pachytodes cerambyciformis & Male & $x$ & SM & 19 & $2 k, 3 k$ & This study \\
\hline Pseudovadonia livida & Male & $\mathrm{x}$ & SM & 19 & $3 b$ & This study \\
\hline Rutpela maculata & Female & $?$ & ? & 20 & - & Teppner, 1968 \\
\hline Rutpela maculata & Male, female & $\mathrm{X} / \mathrm{XX}$ & SM & $19 / 20$ & $2 h, 3 h$ & This study \\
\hline Stenurella melanura & Male & $x$ & SM & 19 & 31 & This study \\
\hline Stenurella nigra & Male & $\mathrm{X}$ & SM & 19 & $3 c$ & This study \\
\hline Stictoleptura maculicornis & Male & $\mathrm{x}$ & M & 19 & 2l & This study \\
\hline Stictoleptura rubra & Male, female & $\mathrm{X} / \mathrm{XX}$ & M & $19 / 20$ & $2 f, 3 f$ & This study \\
\hline Stictoleptura scutellata & Female & $X X$ & SM & 20 & $3 i$ & This study \\
\hline Stictoleptura stragulata & Male, female & $\mathrm{X} / \mathrm{XX}$ & $\mathrm{M}$ & $19 / 20$ & $2 e, 3 e$ & This study \\
\hline
\end{tabular}

\section{X}

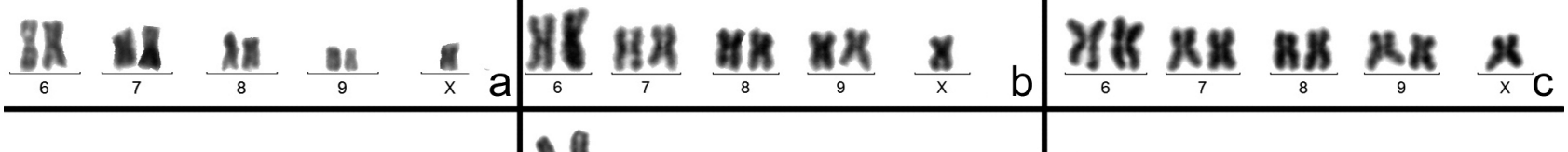

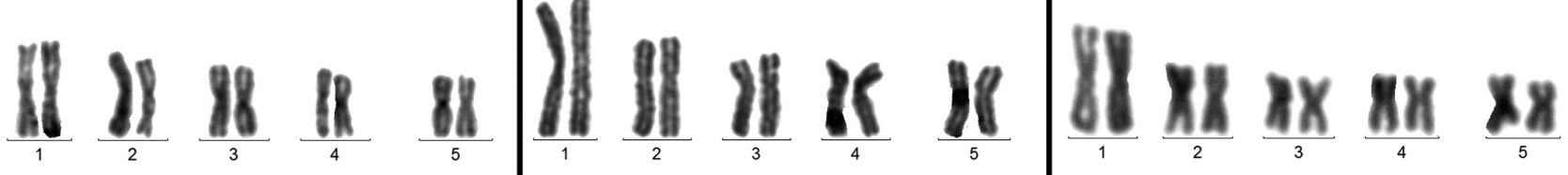

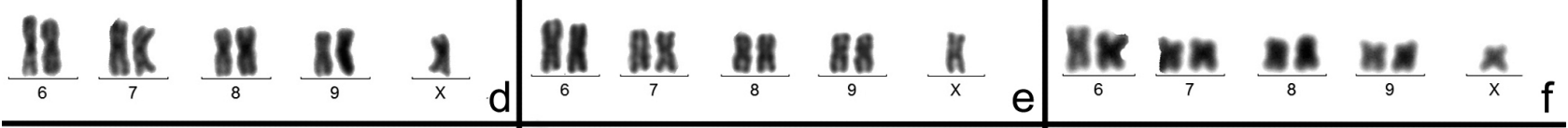

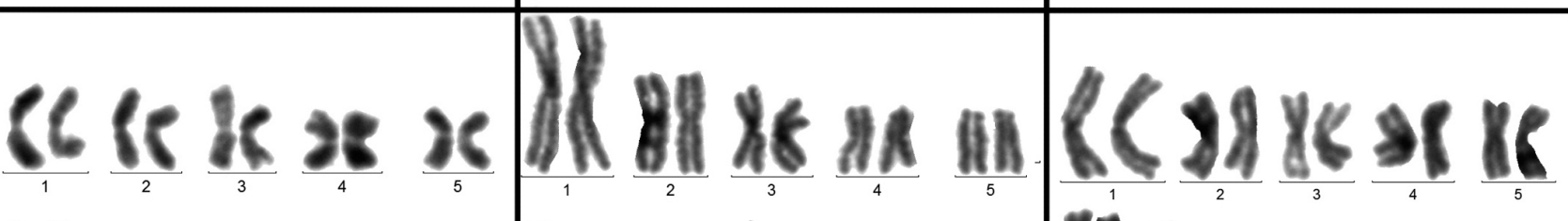

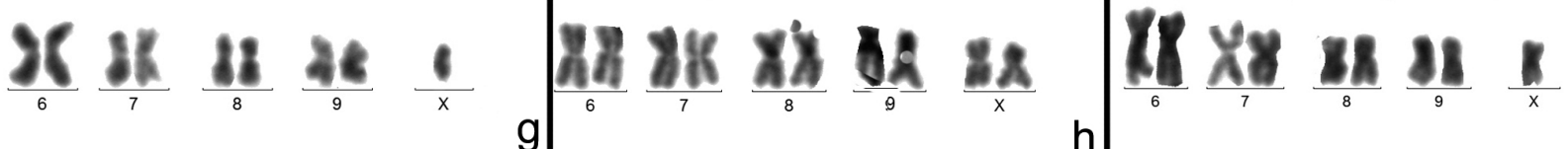

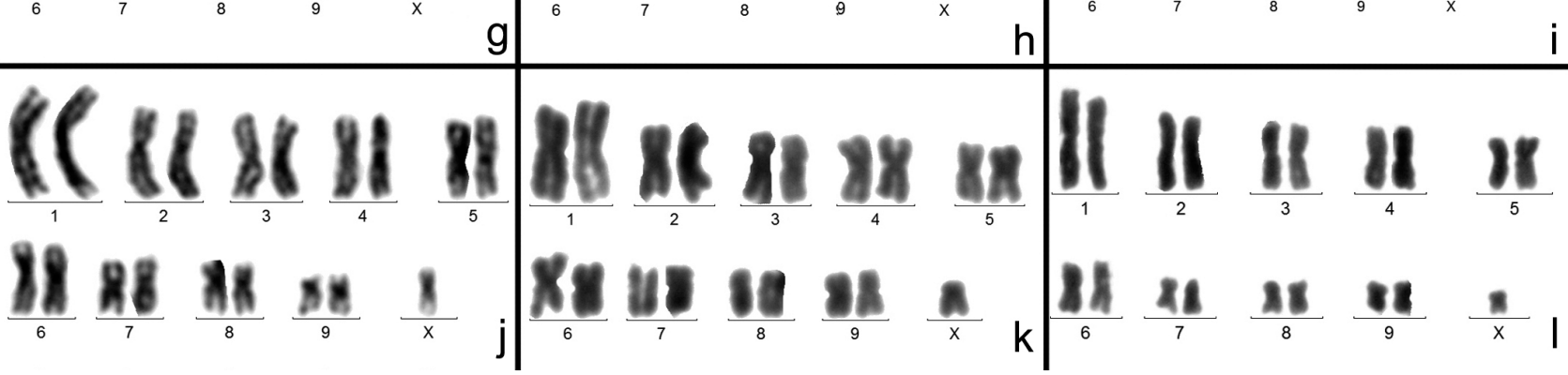

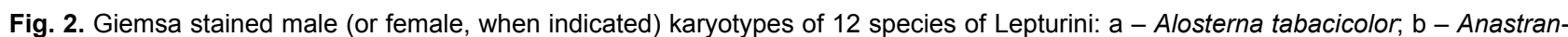
galia dubia; c - A. sanguinolenta; $\mathrm{d}$ - Anoplodera sexguttata; e - Stictoleptura stragulata; $\mathrm{f}-\mathrm{S}$. rubra; $\mathrm{g}$ - Leptura aurulenta; $\mathrm{h}$ - Rutpela maculata (female); i - Leptura quadrifasciata; $\mathrm{j}$ - Lepturobosca virens; $\mathrm{k}$ - Pachytodes cerambyciformis; I - Stictoleptura maculicornis. 


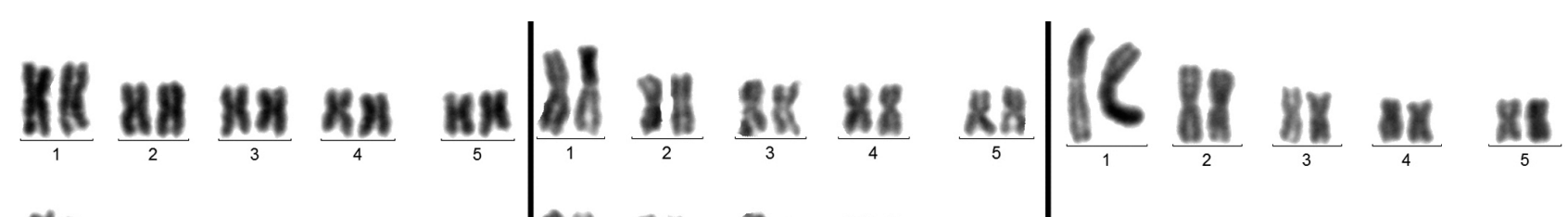

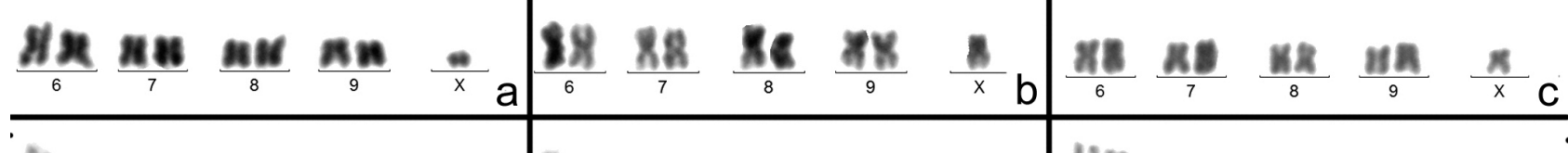

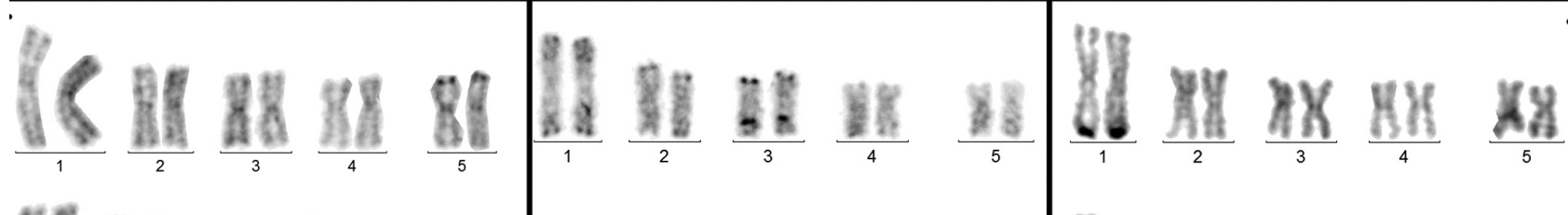

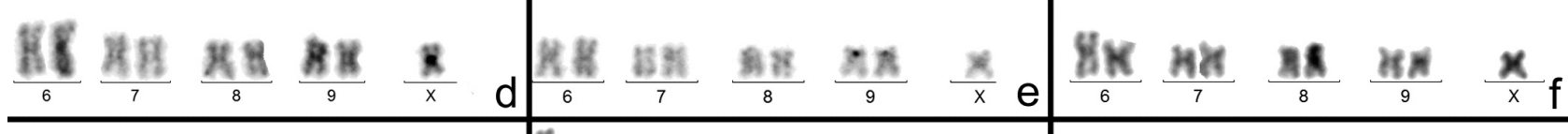

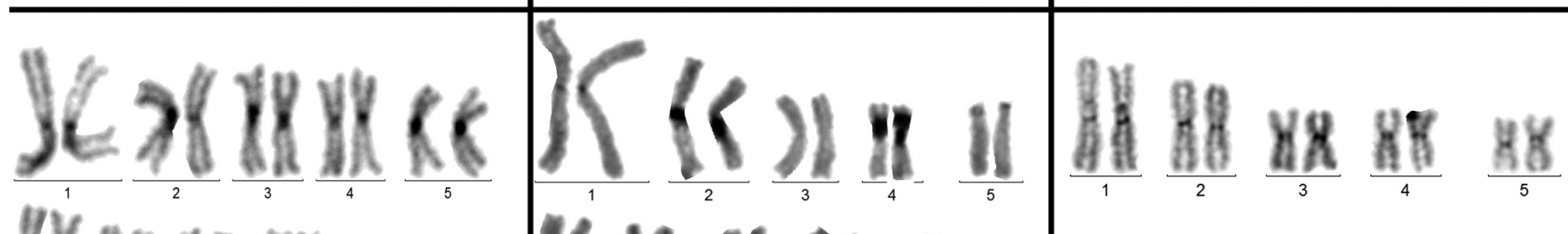

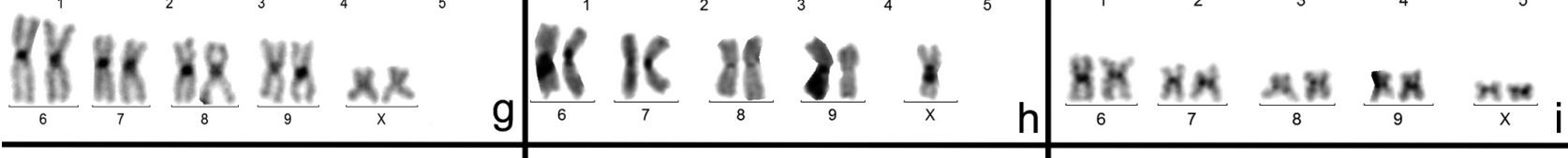

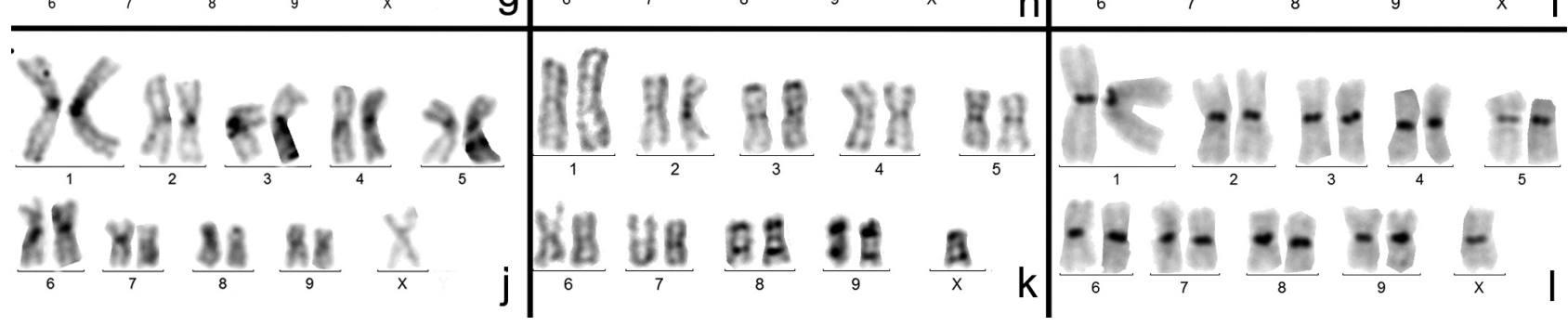

Fig. 3. Giemsa stained $(\mathrm{a}-\mathrm{c})$ and C-banded (d-l) karyotypes of Lepturini (males except g): a - Etorofus pubescens; b - Pseudovadonia livida; c - Stenurella nigra; d - Anastrangalia dubia; e - Stictoleptura stragulata; $\mathrm{f}$ - S. rubra; $\mathrm{g}$ - Leptura aurulenta (female); $\mathrm{h}$ - Rutpela maculata; i - Stictoleptura scutellata; j - Leptura quadrifasciata; k - Pachytodes cerambyciformis; I - Stenurella melanura.

and lost in all or most Lepturini. The two non-Lepturinae species of Cerambycidae reported to lack chromosome Y, S. barbatum (Manna \& Lahiri, 1972) and O. amputator (Dutrillaux \& Dutrillaux, 2008), belong to the Cerambycinae and Lamiinae, respectively. Thus, the known losses of chromosome $\mathrm{Y}$ are the consequence of at least 3 independent events, which occurred in 3 different subfamilies of Cerambycidae. Two of these events seem to be limited to a single or a few species and may be recent. The loss affecting Lepturini may be more ancient, because it is recorded in almost all the species studied and in a total of 17 species and 11 genera. These 11 genera make up about half of those present in Western Europe, but only a small proportion of the world fauna, which is composed of about 120 genera. Indeed, more studies are necessary to determine if the species studied here are representative of all Lepturini or if

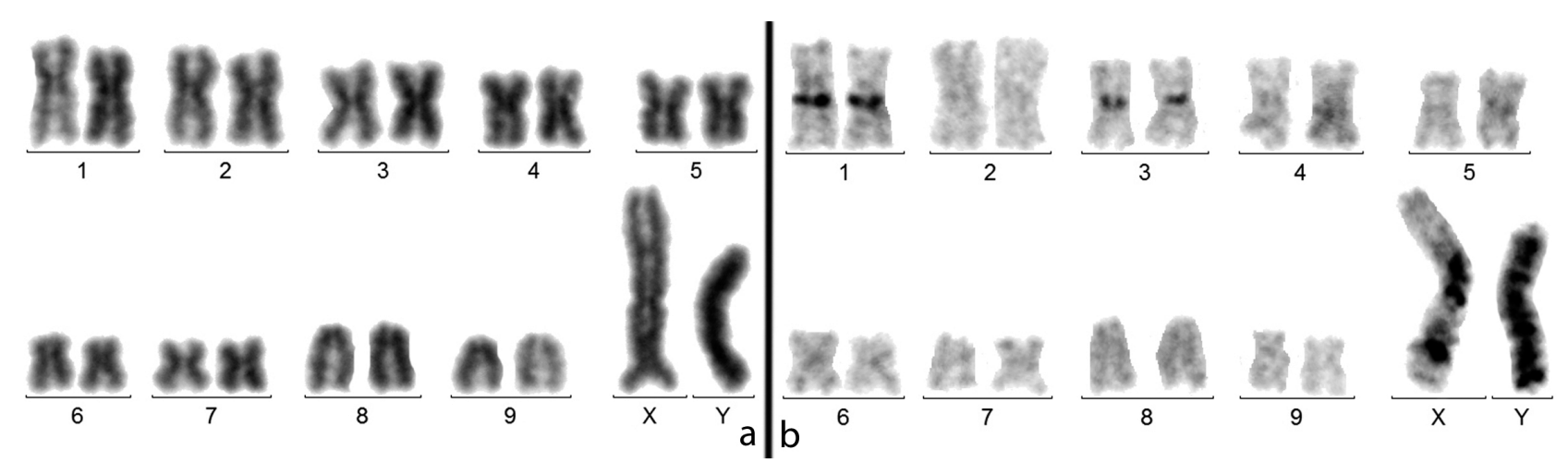

Fig. 4. Giemsa stained (a) and C-banded (b) karyotypes of male Oxymirus cursor. The very large size of the $X$ and $Y$ chromosomes is due to heterochromatin amplification, which is fully $\mathrm{C}$-banded on the $\mathrm{Y}$ and partially $\mathrm{C}$-banded on the $\mathrm{X}$. 
they constitute a clade inside Lepturini. The case of $G$. ruficornis remains ambiguous. The genus Grammoptera Audinet-Serville, 1835 was alternatively classified in Rhagiini or Lepturini, but the most recent classifications favour the Lepturini hypothesis. The presence of a Y chromosome in the male would support the Rhagiini hypothesis, also proposed on the basis of the larvae (Svacha \& Danilevsky, 1989), but is not in agreement with the molecular data of Sýkorová (2008), which places Grammoptera (represented by two species) in Lepturini and far from the monophyletic group of Rhagiini with 22 chromosomes. "Grammoptera" in the molecular tree of Saito \& Saito (2003) is actually Alosterna chalybeella (Bates, 1884), and the sequence is moreover misidentified (P. Švácha, pers. comm.). The multiple nomenclatural changes at the levels of genera and tribes of Lepturinae indicate that objective criteria are lacking (Svacha \& Lawrence, 2014), and indeed, cytogenetic data could help in their systematic classification.

As discussed elsewhere (Dutrillaux \& Dutrillaux, 2017), the presence or absence of chromosome Y seems to have no consequences for the phenotype of the males in beetles: only the balance $\mathrm{X} / \mathrm{XX}$ determines the sex. Chromosome $\mathrm{Y}$ appears to be dispensable, with a role limited to the facilitation of the migration of the $\mathrm{X}$ at meiosis through the $\mathrm{Xy}$ structure. However, in X0 males, other strategies involving nucleolar proteins compensate for the lack of chromosome Y (Dutrillaux \& Dutrillaux, 2017). At metaphase I, the unique $\mathrm{X}$ remains embedded in nucleolar proteins and forms a structure, which was probably interpreted as an $\mathrm{Xy}_{\mathrm{p}}$ in earlier publications. If, as generally accepted, the males of ancestors of Polyphaga had a Y chromosome, the evolutionary trend is its loss. The example of Lepturini, in which the lack of the Y chromosome was completely overlooked, suggests that the occurrence of X0 males may remain undiscovered in other beetle families. This was the case for Cantharidae, in which James \& Angus (2007) found $\mathrm{X} 0$ males in species previously described as having an $\mathrm{Xy}_{\mathrm{p}}$ structure at meiosis.

\section{The deviations in chromosome numbers may define monophyletic taxa}

Considering both the literature (Smith \& Virkki, 1978) and our own data, it appears that the karyotype of a group of species of Rhagiini belonging to the genera Acmaeops, Gaurotes and Dinoptera is composed of 22, and not the 20 chromosomes present in most Cerambycidae (and presumably plesiomorphic). In addition, in species with 22 chromosomes, the size of the autosomes progressively decreases, whereas both in the remaining Rhagiini and Lepturini, there are discontinuities in chromosome sizes. The karyotypes with 22 chromosomes may have been derived from a karyotype with 20 chromosomes by chromosome fission, possibly involving chromosome 1 , which is very large in karyotypes with 20 chromosomes. This is in good agreement with molecular data where the genera with 22 chromosomes, together with some other probably related genera whose karyotypes are unknown (Pseudogaurotina, Lemula, Brachysomida, Rhondia), form monophyletic groups (Saito \& Saito, 2003; Sýkorová, 2008). The in- crease to 24 chromosomes of gradually decreasing size in G. ruficornis may or may not be related to those genera of Rhagiini with 22 chromosomes. Interestingly, the increase in chromosome number may be associated with a developmental particularity: a delayed gametogenesis. In Lepturinae, male gametogenesis ends at the pupal stage (Ehara, 1951; Dutrillaux, 2008). This probably explains the scarcity of cytogenetic data on this subfamily, considering that most of the earlier studies on beetles were done using the gonads of adults. We confirmed the early gametogenesis in most of the species used in this study, with the exception of Gaurotes virginea and Grammoptera ruficornis in which gametogenesis occurs in young adults. The literature survey (Tables 2 and 3) indicates that cytogenetic results on dividing meiotic cells are reported for 5 species belonging to 3 genera: Rhagium bifasciatum, R. inquisitor, Acmaeops proteus, Gaurotes doris and G. suvorovi. The data on the 2 species of Rhagium, were obtained from pre-imaginal stages, confirming their early gametogenesis (Teppner, 1968). In contrast, the data for the two species of Gaurotes were obtained from the imago (Ehara, 1956). The information is not given for $A$. proteus. These 3 last species have 22 chromosomes. No other results on meiotic chromosomes were found for male Lepturinae, and we repeatedly failed to obtain proliferating germ cells in the testicles of the young adults we studied. As a working hypothesis, we propose that those species with 22-24 chromosomes may be also distinguished by their relatively late gametogenesis.

In conclusion, this study of the male sex chromosomes of 11 species of Lepturinae from Western Europe currently classified in the "Rhagiini" (this tribe may not be monophyletic) are of the classical XY type, whereas those of $17 / 18$ species (the exception is Grammoptera ruficornis, which may be misclassified) of Lepturini are X0. Further studies, however are needed to confirm that this loss of chromosome Y characterizes all the species of Lepturini, which could constitute an apomorphy of this tribe whose definition remains controversial. In Rhagiini, a group of species with more than 20 chromosomes and late gametogenesis apparently constitutes a monophyletic group, which is in agreement with the limited available molecular data (Saito \& Saito, 2003; Sýkorová, 2008). With its very large sex chromosomes, the karyotype of $O$. cursor (Oxymirini) is unusual, but their enlargement is due to heterochromatin amplification, a rapid process, which may have little meaning for phylogenetic studies. The $2 \mathrm{n}=20$ female karyotype of Rhamnusium bicolor (Rhamnusiini) may further support the presumption that this should be the plesiomorphic chromosome number.

ACKNOWLEDGEMENTS. We thank P. Švácha (Institute of Entomology, BC CAS, České Budějovice) for his critical and constructive discussions about the manuscript and for providing us with larvae of Oxymirus cursor and Rhamnusium bicolor.

\section{REFERENCES}

ANGUS R.B. 1982: Separation of two species standing as Helophorus aquaticus (L.) (Coleoptera, Hydrophilidae) by banded chromosome analysis. - Syst. Entomol. 7: 275-281. 
Bousquet Y., Heffern D.J., Bouchard P. \& Nearns E.H. 2009: Catalogue of family-group names in Cerambycidae (Coleoptera). - Zootaxa 2321: 1-80.

Dutrillaux B. 2008: A propos des variations de coloration, liées au sexe (hétérochromatisme sexuel) ou non (polychromatisme), chez les Cerambycidae de la faune de France (Coleoptera). - Bull. Soc. Entomol. Fr. 113: 155-172.

Dutrillaux B. \& Chevin H. 1968: Etude cytogénétique de Timarcha goettingensis L. et de T. normanna Reiche (Col., Chrysomelidae). - Bull. Soc. Entomol. Fr. 74: 219-224.

Dutrillaux A.-M. \& Dutrillaux B. 2008: Sex chromosome rearrangements in Polyphaga beetles. - Sex Dev. 3: 43-54.

Dutrillaux A.-M. \& Dutrillaux B. 2017: Evolution of the sex chromosomes in beetles. I. The loss of the Y chromosome. Cytogenet. Genome Res. 152: 97-104.

EHARA S. 1951: Histological structure of male gonads of some cerambycid beetles with remarks on their systematic relationships. - J. Fac. Sci. Hokkaido Univ. (Ser. VI, Zool.) 10: 266270, pl. XII.

EHARA S. 1956: A comparative histology of male gonads in some cerambycid beetles with notes on the chromosomes. - J. Fac. Sci. Hokkaido Univ. (Ser. VI, Zool.) 12: 309-316, pl. IX.

JAMES L.V. \& ANGUS R.B. 2007: A chromosomal investigation of some British Cantharidae (Coleoptera). - Genetica 130 293-300.

LöBl I. \& Smetana A. 2010: Catalog of Palaearctic Coleoptera, Vol. 6. Chrysomeloidea. Apollo, Stenstrup, 924 pp.

MANNA G.K. \& LAHIRI M. 1972: Chromosome complement and meiosis in forty-six species of Coleoptera. - Chrom. Inf. Serv. 13: 9-11.
SAito S. \& SAito A. 2003: Molecular phylogeny analysis of the subfamily Lepturinae (Coleoptera, Cerambycidae). - Konchuto Shizen (Insects and Nature) 38: 17-20 [in Japanese].

Sмiтн S.G. 1953: Chromosome numbers of Coleoptera. - Heredity $7: 31-48$.

Smith S.G. \& Virkki N. 1978: Animal Cytogenetics, Vol. 3, Insecta 5, Coleoptera. Gebrüder Borntraeger, Berlin, pp. 236-290.

Svacha P. \& Danilevsky M.L. 1989: Cerambycoid larvae of Europe and Soviet Union (Coleoptera, Cerambycidae). Part III. - Acta Univ. Carol. (Biol.) 32[1988]: 1-205.

Svacha P. \& Lawrence J.F. 2014: Cerambycidae Latreille, 1802. In Leschen R.A.B. \& Beutel R.G. (eds): Handbook of Zoology, Arthropoda: Insecta Coleoptera, Beetles, Vol. 3. Morphology and Systematics (Phytophaga). W. de Gruyter, Berlin/Boston, pp. 77-177.

SÝKOROvÁ M. 2008: Molecular Phylogeny of Subfamilies Spondylinae and Lepturinae (Coleoptera: Cerambycidae) Based on Mitochondrial $16 S$ RNA. B.Sc. Thesis, University of South Bohemia, České Budějovice, iv + 34 pp. [in Czech]. URL: http://www.theses.cz/id/inccot/downloadPraceContent adipIdno_3930

TEPPNER H. 1966: Chromosomenzahlen einiger mitteleuropäischer Cerambycidae (Coleoptera). - Chromosoma (Berl.) 19: 113-125.

TePpNer H. 1968: Chromosomenzahlen einiger mitteleuropäischer Cerambycidae (Coleoptera). II. - Chromosoma (Berl.) 25: $141-151$.

Received September 14, 2017; revised and accepted January 15, 2018 Published online February 9, 2018 